\title{
TRADE POLICY IN ASIA
}

Higher Education and Media Services 


\section{World Scientific Studies in International Economics}

(ISSN: 1793-3641)

Series Editor Robert M. Stern, University of Michigan and

University of California-Berkeley, USA

Editorial Board Vinod K. Aggarwal, University of California-Berkeley, USA

Alan Deardorff, University of Michigan, USA

Paul De Grauwe, London School of Economics, UK

Barry Eichengreen, University of California-Berkeley, USA

Mitsuhiro Fukao, Keio University, Tokyo, Japan

Robert L. Howse, New York University, USA

Keith E. Maskus, University of Colorado, USA

Arvind Panagariya, Columbia University, USA

Vol. 29 The Social Value of the Financial Sector: Too Big to Fail or Just Too Big? edited by Viral V Acharya (New York University, USA \& Centre for Economic Policy (CEPR), UK), Thorsten Beck (Tilburg University, The Netherlands \& Centre for Economic Policy (CEPR), UK), Douglas D Evanoff (Federal Reserve Bank of Chicago, USA), George G Kaufman (Loyola University Chicago, USA), \& Richard Portes (London Business School, UK\& Centre for Economic Policy (CEPR), UK)

Vol. 30 The Role of Central Banks in Financial Stability: How Has It Changed? edited by Douglas D Evanoff (Federal Reserve Bank of Chicago, USA), Cornelia Holthausen (European Central Bank, Germany), George G Kaufman (Loyola University Chicago, USA) \& Manfred Kremer (European Central Bank, Germany)

Vol. 31 Exchange Rates and Global Financial Policies by Paul De Grauwe (London School of Economics, UK)

Vol. 32 Asian Free Trade Agreements and WTO Compatibility: Goods, Services, Trade Facilitation and Economic Cooperation by Shintaro Hamanaka (Asian Development Bank, Philippines)

Vol. 33 Economics and Politics of Trade Policy by Douglas R Nelson (Tulane University, USA)

Vol. 34 Applied Trade Policy Modeling in 16 Countries: Insights and Impacts from World Bank CGE Based Projects by David G Tarr (Consultant and Former Lead Economist, The World Bank, USA)

Vol. 35 The Floating World: Issues in International Trade Theory by Wilfred J Ethier (University of Pennsylvania, USA)

Vol. 36 Trade Policy in Asia: Higher Education and Media Services edited by Christopher Findlay (University of Adelaide, Australia), Hildegunn Kyvik Nordas (Organisation for Economic Co-operation and Development, France) \& Gloria Pasadilla (APEC Secretariat, Singapore)

The complete list of the published volumes in the series can be found at http://www.worldscientific.com/series/wssie 


\section{TRADE POLICY IN ASIA}

Higher Education and Media Services

\section{Christopher Findlay}

University of Adelaide, Australia

\section{Hildegunn Kyvik Nordas}

Organisation for Economic Co-operation and Development, France

\section{Gloria Pasadilla}

APEC Secretariat, Singapore 
Published by

World Scientific Publishing Co. Pte. Ltd.

5 Toh Tuck Link, Singapore 596224

USA office: 27 Warren Street, Suite 401-402, Hackensack, NJ 07601

UK office: 57 Shelton Street, Covent Garden, London WC2H 9HE

\section{Library of Congress Cataloging-in-Publication Data}

Trade policy in Asia : higher education and media services / edited by Christopher Findlay

(University of Adelaide, Australia), Hildegunn Kyvik Nordas (Organisation for Economic

Co-operation and Development, France) Gloria Pasadilla (APEC Secretariat, Singapore).

pages cm. -- (World Scientific studies in international economics ; vol. 36)

Includes bibliographical references and index.

ISBN 978-9814590198 (hardcover : alk. paper)

1. Education, Higher--Economic aspects--Asia. 2. Transnational education--Economic

aspects--Asia. 3. Mass media--Economic aspects--Asia. 4. Asia--Commercial policy. I. Findlay, Christopher C. (Christopher Charles), editor of compilation. II. Nordås, Hildegunn Kyvik, editor of compilation. III. Pasadilla, Gloria, editor of compilation. IV. Vincent-Lancrin, Stéphan. From cross-border higher education to trade in education services.

LC67.68.A78T73 2014

338.4'3378095--dc23

2014005225

\section{British Library Cataloguing-in-Publication Data}

A catalogue record for this book is available from the British Library.

Copyright (C) 2014 by Asian Development Bank Institute and

Organisation for Economic Co-operation and Development

All rights reserved.

\section{Disclaimer}

The views expressed in this book are those of the authors and do not necessarily reflect the views and policies of the Asian Development Bank Institute (ADBI), nor the Asian Development Bank's Board of Governors or the governments they represent, nor the Organisation for Economic Co-operation and Development (OECD) or the governments of the OECD member countries.

ADBI and OECD each do not guarantee the accuracy of the data included in this publication and accept no responsibility for any consequence of their use. By making any designation of or reference to a particular territory or geographic area, or by using the term "country" in this document, ADBI or OECD does not intend to make any judgments as to the legal or other status of any territory or area.

This publication follows World Scientific Publishing's style and practice. Where there are space constraints, some country names have been abbreviated. In ADB, China is referred to as the People's Republic of China, Korea as the Republic of Korea, Kyrgyzstan as the Kyrgyz Republic, and Russia as the Russian Federation.

In-house Editors: Lee Xin Ying/Philly Lim 


\section{AUTHOR AFFILIATIONS}

\section{Chapter 1}

Professor Christopher Findlay is the Executive Dean of the Faculty of the Professions at the University of Adelaide, Australia.

Hildegunn Kyvik Nordas is a Senior Policy Analyst at the OECD.

Gloria Pasadilla is a Senior Analyst in the APEC Policy Support Unit.

\section{Chapter 2}

Stéphan Vincent-Lancrin is a Senior Analyst and Project Leader at the OECD Directorate for Education and Skills.

\section{Chapter 3}

Professor Zhu Xingde is based at the Center for International Education Study, Ministry of Education and the Shanghai Academy of Educational Sciences, People's Republic of China.

\section{Chapter 4}

Jane Drake-Brockman is based at the Department of Decision Sciences and Managerial Economics at the Chinese University of Hong Kong.

\section{Chapter 5}

Shintaro Hamanaka is an Economist at the Office of Regional Economic Integration, Asian Development Bank. 


\section{Chapter 6}

Siew Yean Tham is Professor and Deputy Director at the Institute of Malaysian and International Studies (IKMAS), Universiti Kebangsaan Malaysia (National University of Malaysia).

\section{Chapter 7}

Toh Mun-Heng is with the Department of Strategy and Policy, National University of Singapore.

\section{Chapter 8}

Gillian Doyle is Professor of Media Economics and Director of the Centre for Cultural Policy Research, University of Glasgow.

\section{Chapter 9}

Arpita Mukherjee is a Professor at the Indian Council for Research on International Economic Relations (ICRIER).

\section{Chapter 10}

Yeongkwan Song is a Fellow, Department of Industry and Service Economy at the Korea Development Institute (KDI). 


\section{PREFACE}

Since the crafting of a services trade agreement in the WTO, business and policy makers have increasingly appreciated the significant role of the services sector in the economy, and particularly its importance in global trade. Services are not only significant inputs in all major traded goods, but have themselves become tradable.

Discussions about unlocking the great potential of services trade have long centered on regulatory reforms, liberalizing foreign investments, entry of foreign services providers, and mobility of service professionals. Regulatory discussions, however, become more meaningful, less abstract and better understood at the sectoral level because regulatory challenges are unique to each. Indeed, the distinct modes of service delivery offer a better opportunity to understand how competition is hampered or facilitated by regulations.

This book is the result of joint research between the ADBI and the OECD that aims to shed more light on what shapes trade in services. The two sectors selected, higher education and audiovisual services (AVS), have benefited immensely from the information technology (IT) revolution. IT has opened new avenues for access to information, knowledge and entertainment, and Asian suppliers have been highly successful in identifying and taking advantage of these new opportunities.

In tertiary education, there has been a rapid increase in recent years in the number of foreign university campuses in Hong Kong, China; Malaysia; and Singapore. The research in this volume provides useful lessons for Asia based on the experience of these economies. At the global level, lessons can be drawn on issues such as accreditation, quality assurance, and mutual recognition of degrees, all issues that OECD economies have had to grapple with.

Movies, broadcasting, and music are audiovisual services (AVS) in which Asia has figured prominently. This book presents the case of two successful exporters of audiovisual services, India and the Republic of Korea, and examines the various issues and challenges they have been 
confronted with, including cultural policy issues and intellectual property rights.

We thank the authors and editors of this volume for their efforts in putting together these studies, and on behalf of the editors we thank Aletha Blayse for preparing the manuscript. We hope that policy makers, business people, researchers and students will gain insights from the collection.

Masahiro Kawai

Dean \& CEO

ADB Institute
Ken Ash

Director

Trade and Agriculture Directorate, OECD 


\section{TABLE OF CONTENTS}

Author Affiliations $\quad$ V

Preface vii

Masahiro Kawai and Ken Ash

1 Overview

Christopher Findlay, Hildegunn Kyvik Nordas, and Gloria Pasadilla

2 From Cross-Border Higher Education to Trade in Education Services

Stéphan Vincent-Lancrin

3 Regulating Higher Education Services in the People's Republic of China

Xingde Zhu

4 Trade and Investment in Higher Education Services in Hong Kong, China

Jane Drake-Brockman

5 International Transactions in Tertiary Education Services:

The Case of Japan

Shintaro Hamanaka

6 Trade Liberalization and Domestic Regulations:

Implications for Malaysia as a Regional Education Hub

Siew Yean Tham

7 Internationalization of Tertiary Education Services in Singapore

Mun-Heng Toh 
8 Audiovisual Services: International Trade and Cultural Policy

Gillian Doyle

9 Audiovisual Services in India 335 Arpita Mukherjee

10 Audiovisual Services in the Republic of Korea: Market Development and Policies Yeongkwan Song 